\title{
Dynamics of Labour Input and Average Annual Hours Actually Worked Per Worker in Industry of Developed Countries and Russia: Similarities and Differences
}

\author{
Alexander Vladimirovich Zolotov ${ }^{1}$, Oleg Anatolevich Mazur ${ }^{2} \&$ Michael Vasilevich Popov ${ }^{3}$ \\ ${ }^{1}$ Lobachevsky State University of Nizhni Novgorod, Nizhni Novgorod, Russian Foundation \\ ${ }^{2}$ Nevinnomissky Institute of Economy, Management and Low, Nevinnomissk, Russian Foundation \\ ${ }^{3}$ Saint Petersburg State University, St.Petersburg, Russian Foundation \\ Correspondence: Alexander Vladimirovich Zolotov, Lobachevsky State University of Nizhni Novgorod, \\ Bolshaya Pokrovskaya Street, House 37, Room 119, 603950, Nizhni Novgorod, Russian Foundation.
}

\author{
Received: December 26, 2014 Accepted: March 28, 2015 Online Published: May 22, 2015 \\ doi:10.5539/ass.v11n14p205 URL: http://dx.doi.org/10.5539/ass.v11n14p205
}

\begin{abstract}
Dynamics of labour input and average annual hours actually worked per worker in industry of developed countries and Russia is analyzed. It is revealed that the correspondence of the given notions depends on the dynamics of employment. It is discovered that for the economically developed countries the quicker reduction of labour input is characteristic in comparison with the employment. In Russian industry labour input is decreasing as well though the employment is decreasing quicker. As a result in economically developed countries average annual hours actually worked per worker in industry is decreasing and in Russia is increasing.
\end{abstract}

Keywords: labour productivity, labour input, average annual hours actually worked per worker

\section{Introduction}

In the recent decades in industry of economically developed countries two important social-economical processes went together: the decrease of average annual hours actually worked per worker on the one hand and the reduction of labour input on industrial production on the other.

The reduction of working time is the continuation of a trend characteristic for the XX century. In 1950-70s the reduction of the working time went on quicker than in the following period. In the first decade of the XXI century this process was going on, but its irregularity had grown, motives and ways of its realization had become more difficult (ILO, 2011).

In economics literature the reduction of working time is rightfully connected with labour productivity rising when the part of the effect reached is used for living standards rising by free time enlargement (Glyn, 2006). Modern workers can satisfy their increased needs spending less time for the paid work than their predecessors (Ridley, 2012).

The reduction of the working time goes on not without the problems. Partially it is neutralized by overtime work (Nordstrom, 2004). Nevertheless all these problems are being solved successfully finally.

Really, with increase of labour productivity in the unit of time to satisfy the fixed social demand less working time amount is necessary. As a result the tendency to reduce the general fund of working time in industry arises which allows to free time for social activity satisfying intellectual, esthetic etc. demands of society.

In the period prior to machine industry the growth of labour productivity was restricted by the fact that labour means were brought to the action by the worker. The limitation of physical human abilities put barriers to such growth of labour productivity which would allow to provide the enlargement of product dictated by the growth of population number and increase of demands at large-scale time-safety from industrial production. That is why historically up to the time of industrial revolution the general value of nonproductive social activity of society though was growing in its absolute value, was relatively less in comparison with the growing general fund of working time in industry and agriculture.

The foundation of machine industry had changed the situation in a principal way: the growth of labour productivity had accelerated so that the growth of social product began to forestall the growth of labour input of 
the society. Thus, e.g. during the XX th century with the growth of the world population from 1.6 bn people to 6 bn the world manufacturing output had become 50 times more whereupon the employment in manufacturing had become 6.5 time more (Marsh, 2012). Average annual hours actually worked per worker in industry decreased at that.

Since 1900 to 1980 the employment in manufacturing - the dominating industrial sector of developed countries - has grown more than three times. And only in the last 30 years in rich countries the decrease of employment in manufacturing takes place and especially quickly beginning with the year 2000 . No doubt the decrease of employment in industry did not reflect the dynamics of labour input extremely precisely, taking into account the reduction of working time existing simultaneously. Nevertheless it does not cancel the fact of labour input general growth in industry of the leading countries in the first half of the XX century.

The decrease of labour input in industry under the condition of output growth shows that the economy became really developed.

The regularity of labour input decrease does not predetermine the dynamics of normal length of working time of a certain worker. It is also necessary to take into account the value of employment and its changing.

Hypothetically this regularity can be fulfilled at different variants of correlation of labour input and the employment in industry.

The variant is possible when the number of workers either stays the same or is decreasing slower than the labour input is decreasing. In this case, the objective precondition of each worker working time shrinking appears with the increase of wellbeing of all members of society.

One more variant consists in the growth of employment in industry simultaneously with decrease of labour input. It would allow to reduce the working time of each worker in a large scale than it dictated by the growth of labour productivity.

Moreover, we can not exclude the situation when reduction of labour input is accompanied by forestalling decrease of the number of employees in industry. It would demand more hours actually worked per worker.

The hypothesis of our investigation is as follows: the reduction of the working time is typical for the developed countries in conditions when the decrease of labour input goes before the decrease of employment.

\section{Materials and Methods}

To verify this hypothesis the data about the dynamics of labour input, average annual hours actually worked per worker for the developed countries which are the leaders in world industrial production will be analyzed. Doing this we shall use the statistical data of the Organization for Economic Co-operation and Development (OECD). As in the data base of OECD the data about labour input in the industry of Japan are absent, we do not analyze the experience of this country.

The statistics of OECD contains the data concerning average annual hours actually worked per worker and wage without the division of the employees according to the kinds of activity. We consider that the dynamics of these indexes for those working in industry corresponds to general dynamics.

The dynamics of the mentioned values will be examined by the correlation of their meaning in 2007 and 2000 . The choice of this period is conditioned not only by the availability of the necessary data. These years were characterized by the growth of industrial production, the changing of the values under the analysis was not distorted because of the world economic crisis.

As for Russia, to evaluate the investigated processes the data of Russian statistics are used which forces us to consider a little bit different period of industry development $-2005-2010$ years.

\section{Results for a Number of Developed Countries}

In Table 1 the corresponding data for a number of developed countries are given.

It is necessary to state that for developed countries the absolute reduction of labour input in industry is typical. Such reduction is well combined with both the satisfaction of the growing needs and the population growth. Evidently, for the nearest perspective this tendency may be regarded as the leading one for this sector of the world economy.

It is evident from the data given in Table 1 for the industrially developed countries the reduction of the employment in industry is also typical. But this reduction takes place slower than the reduction of labour input in industry. As a result average annual hours actually worked per worker are reduced. 
Table 1 . The dynamics of labor input, employment in industry and also average annual hours actually worked per worker and real wage a year in the total economy in 2000-2007 years (the change in \% to the year 2000)

\begin{tabular}{ccccccc}
\hline & United Kingdom & Korea & United States & France & Germany & Sweden \\
\hline Industry & & & & & & \\
Labour input & -26.1 & -9.4 & -19.6 & -13.6 & -9.3 & -8.7 \\
Employment & -2.2 & +1.9 & -8.3 & -7.1 & -6.9 & -3.9 \\
Total economy & & & & & \\
$\quad$ Average annual hours & -1.4 & -8.2 & -2.1 & -2.5 & -3.3 & -1.5 \\
$\quad$ Real wage & +13.2 & +18.9 & +8.7 & +8.4 & +1.5 & +13.8 \\
\hline
\end{tabular}

Source: is based on the OECD data

The dynamics of the indexes under the investigation in the US is analogues to the dynamics in the European countries, though the investigators pay attention more often on the specificity of working time reduction in the USA (Bell \& Freeman, 2001).

In 2000-2007 years only in Korea the reduction of labour input in industry went together with the increase of employment. As it was to be expected it led to higher tempos of time reduction per worker. Though the dynamics of employment in Korea can not be regarded as typical for the developed countries (the growth of employment in industry is characteristic to China, for instance (Knight \& Song, 2005)).

No doubt, that in conditions when new technologies and techniques demand the increase of qualification-education workers level, their responsible and creative attitude to labour the working time shrinking becomes not only a possibility but also a necessity.

The fact that the variant of forestalling employment decrease is purely hypothetical is quite explainable. The case assuming the time absorption for human development by labour is not typical for social progress.

If also follows from the data of Table 1 that in modern economy conditions the contraction of labour input in industry is, mainly, in the form of employment contraction in it. Thus, the tempos of employment contraction in industry were 4times higher than the tempos of average annual hours actually worked per worker contraction in the USA, 2.9 times higher in France, 2.6 times higher - in Sweden, 2.1 times higher - in Germany and 1.6 times - in the UK.

Though the working time shrinking took place initially in the form of working day contraction, it is not the only possible variant of working time shrinking. In the limits of a year, e.g., working time can be reduced due to the increase of holiday days and days of vacation at more or less stable duration of the working week.

We can judge about the correlation of different ways of working time reduction in developed countries taking in account the data of Table 2 .

Table 2. Average annual hours actually worked per worker in total economy, the duration of working week and the duration of vacations and days off in a number of developed countries in relation to the corresponding indexes in Germany in 2007 (\%)

\begin{tabular}{cccccccc}
\hline & $\begin{array}{c}\text { United } \\
\text { Kingdom }\end{array}$ & Korea & $\begin{array}{c}\text { United } \\
\text { States }\end{array}$ & France & Germany & Sweden & Japan \\
\hline Correlation of average annual hours & 117,9 & 162,2 & 126,4 & 104,4 & 100 & 113,8 & 125,5 \\
Correlation of duration of working week & 103,9 & 118,2 & 107,1 & 97,6 & 100 & 97,4 & 113,0 \\
$\begin{array}{c}\text { Correlation of duration of vacations and } \\
\text { days off* }\end{array}$ & 83,5 & $\ldots$ & 50,0 & 89,7 & 100 & 88,5 & $\ldots$ \\
\hline
\end{tabular}

Source: is based on the OECD data, ILO data and (Alesina et al., 2005)

As the given data show, the average annual hours actually worked per worker in Germany in 2007 was minimal among the countries mentioned (it was equal to $1422 \mathrm{hrs).} \mathrm{Meanwhile} \mathrm{the} \mathrm{mean} \mathrm{duration} \mathrm{of} \mathrm{working} \mathrm{week} \mathrm{in}$ Germany manufacturing exceeded the corresponding indexes of France and Sweden.

It also attracts attention that relevant exceeding of the average annual hours actually worked per worker in the countries mentioned in comparison with the index in Germany in all cases considerably exceeds the relevant exceeding of working week continuity. This is explained by a more noticeable number of days of vacations and days off in Germany. 
Such situation was forming for decades. In Germany since 1983 till 2007 the average annual hours actually worked per worker reduced from $1809 \mathrm{hrs}$ to $1422 \mathrm{hrs}$, i.e. on $22.4 \%$ and the working week in manufacturing from $40.5 \mathrm{hrs}$ to $38.5 \mathrm{hrs}$ correspondingly, i.e. on $4.9 \%$.

Consequently, a quarter of a century of working time shrinking in Germany was used predominantly to increase the duration of vacations and days off.

Likewise, the freeing up of the time from production was distributing in France, where the average annual hours actually worked per worker from 1983 to 2007 contracted from $1785 \mathrm{hrs}$ to $1485 \mathrm{hrs}$ (17.8\%) and working week - from 38.9 to $37.6 \mathrm{hrs}(3.3 \%)$.

It is only in Korea where since 2000 to 2007 the average annual hours actually worked per worker contracted on $8.2 \%$ (from $2512 \mathrm{hrs}$ to $2306 \mathrm{hrs}$ ) and working week - on $7.7 \%$ (from $49.3 \mathrm{hrs}$ to $45.5 \mathrm{hrs}$ ), the economy of labour was used almost completely for working week contraction. But this country is very far from the indexes of the countries leading in supplying the workers with free time.

As in majority of industrially developed countries the working week is 5 days long (and 2 days off), the reduction of a working week may testify (to a certain degree) to a reduction of working day. Complete identification of these processes would be incorrect: e.g. the introduction of 35 hrs working week in France didn't mean the automatic reduction of the hours of every working day. Under the collective bargain, often the working hours before the days off were reduced.

\section{Results for Russia}

In Russia before the beginning of the 90 -s there was the increase of industrial production. More than that, according to the soviet statistics in the period from 1980 to 1987 labor productivity in industry had increased on $28 \%$ (GKS, 1988). The dynamics of labour input had principal specificity though. The number of workers in industry since 1980 up to 1987 had grown on $0.1 \%$ and the number of working days - on $0.5 \%$. Thus labour input in Russian industry had grown, though unremarkably. Meanwhile in economically developed countries in the same time period there already were the tendencies to labour input reduction in this sphere of economy.

The average annual hours actually worked per worker in Russia was equal to $1900 \mathrm{hrs}$ and exceed in that period the analogues indexes of the developed countries on 100-200 hrs.

In the 90-s in Russia there was a deep fall of industrial production. In 1998 it was only 46\% in comparison with 1990 (GKS, 2013). The reduction of working time happened then for sure had a crisis character. It was followed by the abrupt fall of real wages and the appearance of mass poverty.

Beginning with 1999 the restoration of industrial production began. The main source of growth is the increase in labour productivity. For example, in the period $2005-2010$ years the volume of manufacturing production had increased on $14.1 \%$, labour productivity in this leading sphere of industry had grown on $25.3 \%$ and labour input hag reduced in manufacturing on $7.7 \%$ at that.

The number of employees in manufacturing decreased on $11.6 \%$ since 2005 up to 2010 but labour input had decreased only on $7.7 \%$. As a result the average annual hours actually worked per worker in this sphere had increased on $3.1 \%$ and reached 1895 hours according to our estimation.

In 2012 the employment in manufacturing reduced on $1.1 \%$ in comparison with 2010, though labour input increased on $0.3 \%$. Correspondingly the average annual hours actually worked per worker grewon $1.5 \%$ and reached, according to our calculation, $1924 \mathrm{hrs}$. The given value corresponds to the level which existed in Russian industry in the 80 -s.

What is the reason of an employment reduction in manufacturing? These are: more difficult working conditions than in the sphere of "office economy" and, what is not the least important, the longer working time (in 2011 the working week of qualified workers in industry on $2.2 \mathrm{hrs}$ exceed the working week of the specialists of the highest level of qualification and on $1.7 \mathrm{hrs}$ - the specialists with medium level of qualification (GKS, 2012).

The analogues reduction of employment with simultaneous increase of working time duration justifies the deficit of labour resources in manufacturing. . One of its criterion is the growth of vacancies number in the given sphere. Thus, only the number of such vacancies grew from 77000 in 2010 to 110300 in 2012 (GKS, 2013). Though the vacancies do not exceed $1 \%$ from the number of employees but with taken into account the old age of qualified workers and negligible inflow of young employees, it is possible to forecast the problem sharpening in the nearest future already.

Under such conditions the use of labour migration is regular as the factor of labour supply increase. 
According to the official data the number of foreign migrants in manufacturing Russia had grown from 48700 people in 2005 to 167300 in 2012 or from $0.4 \%$ out of number of employees in manufacturing to $1.6 \%$ (GKS, 2013).

It is known that the duration of migrants working time is higher than that of local workers up to $10-20 \%$.

It is also necessary to take into consideration internal migration into manufacturing in Russia. Thus, if in 2010 there were 172800 of such migrants, in 2012 there were already 219700 of them. The share of internal migrants among employees in this sphere grew respectively from $1.7 \%$ to $2.2 \%$. The length of working time of such migrants is close to that of foreign migrants.

So, migrants share in manufacturing according to the most minimal evaluation is $4 \%$. The time worked by them additionally (200 hrs per year) increases labour input on $0.4 \%$. In this case, the average annual hours actually worked per non-migrant worker appear to be $8 \mathrm{hrs}$ less and is equal $1916 \mathrm{hrs}$.

No doubt, this clarification does not cancel the general conclusion about the of working time in manufacturing of Russia, especially taking into account that the majority of migrants are Russian workers.

More than that, in Russia labour input in the personal plot is unusually high (for the developed countries): it is $95 \%$ of labor input in manufacturing. The largest part of this work is that of the industrial workers. Hence, the rest time of Russian workers is in fact less than it would be expected if we take into account the statistics of average annual hours actually worked per worker.

\section{Discussion}

The decrease of labour input in the developed countries makes it possible to reduce the working time of employees which happens in reality. It was a long-run tendency (Alesina et al., 2005; Bosch \& Lehndorff, 2001) which provided the rise of living standards (Bowman, 2014; Chang, 2011).

In Russia labour input decrease in manufacturing was also taking place. Since the end of 1990-s the growth of labour productivity has been being observed. During this period of time the average wage in industry has also grown. Nevertheless, at present the duration of working time in manufacturing is on the level of the end of the 80 -s. The gap between the developed countries and Russia has grown on 200-300 hrs and reached 300-500 hrs per year.

For the last 25 years the position of industrial workers from the point of view of the free time they possess has not improved which contrasts drastically with the progress in the developed countries. From our point of view, it is an example of the contrast between the different perspectives of income and capability (Sen, 2001).

The growing of working time duration in Russia has both direct and long-run negative consequences.

In the manufacturing of Russia elderly workers prevail. It is not very easy for them to cope with labour loading increase. Moreover, the lengthening of working time is one of the reasons of young workers deficit in industry.

The increase of labour migration to a certain extent compensates the deficit of labour force in manufacturing. Though, the main source of such migrants are qualified workers of former soviet plants. Evidently, this reserve will be finished during the nearest 5-10 years. More than that, the elongation of working time thanks to the use of migrants labour lessens the labour attractiveness in manufacturing for Russian workers.

Thecoursetotheincreaseofworkingtimeunderminetheinterestofentrepreneursintheuseofnewtechnologies, preserve the backwardness of Russian manufacturing, deprives the enterprises of competitiveness.

Surely, the way of working time increase in Russian industry is not perspective (Mazur, 2009).

In Russian economy it is necessary to take into the account the experience of the developed countries which proves the necessity of both labour input decrease and the average annual hours actually worked per worker in industry (Gubanov, 2012).

\section{Conclusion}

The developed countries and Russia have the following fact in common: the growth of industrial production on the basis of labour productivity rise is accompanied by labour input decrease. This situation differentiates them from developing countries where industrialization is accompanied by the growth of a number employees in industry and the increase of labour input in it.

At the same time in the developed countries the reduction of labour input in industry though accompanied by the employment reduction has the tempos higher than the last one. It provides grounds for employees free time growth. 
In Russia the employment in manufacturing is decreasing quicker than labour input. It leads to the prolongation of working time.

In the context of the problem under discussion it is necessary to further study the influence of reindustrialization on employment dynamics in industry. If a number of employees grow, labour input contraction can give a new impulse to working time shrinking.

In Russia they also started to speak about reindustrialization and creation of 25 million of effective working places which makes the continuity of this problem investigation acute.

It is necessary to take into account how many hours workers work during their working life. It is known that in Russia the workers retire 3-5 years earlier than in developed countries. It makes it possible to believe that longer average annual hours actually worked per worker are compensated in Russia by a smaller number of years of working life. It is evident that without solving this question the comparison of working time dynamics in developed countries and Russia is not complete.

\section{References}

Alesina, A., Glaeser, E., \& Sacerdote, B. (2005, April). Work and Leisure in the U.S. and Europe: Why so Different? Harvard Institute of Economic Research. Discussion Paper Number 2068. Retrieved October 10, 2012, from http://www.post.economics.harvard.edu/hier/2005papers/2005list.html

Bell, L. A., \& Freeman, R. B. (2001). The incentive for working hard: explaining hours worked differences in the US and Germany. Labour Economics, 8.

Bosch, G., \& Lehndorff, S. (2001). Working-time reduction and employment: experiences in Europe and economic policy recommendations. Cambridge Journal of Economics, 25, 220.

Bowman, J. R. (2014). Capitalism Compared: Welfare, Work, and Business (p. 376). CQ Press.

Chang, H.-J. (2011). 23 Things They Don't Tell You about Capitalism (p. 286). Penguin Books.

GKS. (1988). National Economy of the USSR in 1987 (p. 615). Yearbook. Moscow.

GKS. (2012). Research of problems of Employment. Retrieved November 14, 2012, from http://www.gks.ru/ bgd/regl/b11_30/Main.htm

GKS. (2013a). Labour and Employment in Russia. Retrieved October 11, 2013, from http//www.gks.ru/bgd/regl/ B0248/IssWWW.exe/Stg/d010/i010020r.htm

GKS. (2013b). Russian Statistic Yearbook. Retrieved January 15, 2014, from http://www.gks.ru/bgd/regl/ b13_13/Main.htm

Glyn, A. (2006). Capitalism Unleashed: Finance, Globalization, and Welfare (p. 242). Oxford University Press.

Gubanov, S. (2012). Neoindustrialization of Russia and Vertical Integration (pp. 48-49). Moscow.

ILO. (2011). Working time in the twenty-first century: Discussion report for the Tripartite Meeting of Experts on Working-time Arrangements 2011. Retrieved October 10, 2012, from http//www.iloorg/wcmsp5/groups/ public/edprotect/protrav/travail/documents/publication/wcms1674.pdf

Knight, J., \& Song, L. (2005). Towards a Labour Market in China (p. 258). Oxford University Press.

Marsh, P. (2012). The new industrial revolution: consumers, globalization and the end of mass production (p. 311). Yale University Press.

Mazur, O. (2009). Development of workers of modern Russia (p. 222). Sankt Petersburg University Press.

Nordstrom, S. O. (2004). The impact of working- time reductions on actual hours and wage: evidence from Swedish register-data. Labour Economics, 11(5), 647-665.

Ridley, M. (2012). Of predictions and progress: more for less. In D. Franklin, \& J. Andrews (Eds.), Megachange (pp. 264-275). The world in 2050.Edited by The Economist Newspaper Ltd.

Sen, A. (2001). Development as Freedom (p. 366). Oxford University Press.

\section{Copyrights}

Copyright for this article is retained by the author(s), with first publication rights granted to the journal.

This is an open-access article distributed under the terms and conditions of the Creative Commons Attribution license (http://creativecommons.org/licenses/by/3.0/). 